\title{
Purification and characterization of a heteromultimeric glycoprotein from Artocarpus heterophyllus latex with an inhibitory effect on human blood coagulation
}

\author{
Jaruwan Siritapetawee ${ }^{1,2 \varpi}$ and Sompong Thammasirirak ${ }^{3}$ \\ 1Department of Pathology, Institute of Medicine, and 2School of Biochemistry, Institute of Science, Suranaree University of Technology, Thailand; \\ 3 Protein and Proteomic Research Group, Department of Biochemistry, Faculty of Science, Khon Kaen University, Thailand
}

Plant latex has many health benefits and has been used in folk medicine. In this study, the biological effect of Artocarpus heterophyllus (jackfruit) latex on human blood coagulation was investigated. By a combination of heat precipitation and ion-exchange chromatography, a heat stable heteromultimeric glycoprotein (HSGPL1) was purified from jackfruit milky latex. The apparent molecular masses of the monomeric proteins on SDS/PAGE were 33,31 and $29 \mathrm{kDa}$. The isoelectric points $(p / s)$ of the monomers were $6.63,6.63$ and 6.93 , respectively. Glycosylation and deglycosylation tests confirmed that each subunit of HSGPL1 formed the native multimer by sugar-based interaction. Moreover, the multimer of HSGPL1 also resisted 2-mercaptoethanol action. Peptide mass fingerprint analysis indicated that HSGPL1 was a complex protein related to Hsps/chaperones. HSGPL1 has an effect on intrinsic pathways of the human blood coagulation system by significantly prolonging the activated partial thrombin time (APTT). In contrast, it has no effect on the human extrinsic blood coagulation system using the prothrombin time (PT) test. The prolonged APTT resulted from the serine protease inhibitor property of HSGPL1, since it reduced activity of human blood coagulation factors $\mathrm{XI}_{\mathrm{a}}$ and $\mathrm{a}-\mathrm{XII}$.

Keywords: Artocarpus heterophyllus, moraceae, jackfruit, latex, blood coagulation

Received: 21 March, 2011; revised: 05 July, 2011; accepted: 17 September, 2011; available on-line: 30 November, 2011

\section{INTRODUCTION}

Artocarpus heterophyllus (jackfruit) belongs to the family Moraceae, which is widely distributed in tropical areas including Thailand (Kabir, 1995; Mekkriengkrai et al., 2004; Shyamalamma, 2008). The plant has many potential health benefits. For example, jackfruit seeds are found to be a good source of mineral elements (Ajayi, 2008). Potassium is the prevalent mineral element, followed by sodium, magnesium and calcium (Ajayi, 2008). In addition, some parts of jackfruit have been used in folk medicine. For instance, its leaves and roots have been used for anemia, asthma, dermatosis, diarrhea and as an expectorant for coughs (Fernando et al., 1991).

Jackfruit is also a rubber-producing plant, as all parts of the tree contain sticky white latex (Prasad \& Virupaksha, 1990; Mekkriengkrai et al., 2004). Latex is an aqueous emulsion found in the vacuoles of special secretory cells known as laticifers, which contain lipids, rubbers, resins, sugars, many proteins and enzymes (Fonseca et al., 2010). It has been shown that some plant latex has medicinal properties. For example, fig tree latex has been used to treat warts in short-duration therapy with no reports of any side-effect (Bohlooli et al., 2007). Plant latex has clot inducing and dissolving properties in human hemostasis (Osoniyi \& Onajobi, 2003; Shivaprasad et al., 2009). Moreover, plant latex is widely used in the developing countries as an effective treatment for wound healing. Carica papaya latex has been used for wound healing in mice burn (Gurung \& Skalko-Basnet, 2009). In addition, ethanolic and dichloromethane extracts of Mammea americana latex have been found to possess excellent antisecretory and/or gastroprotective effects in all gastric models (Toma et al., 2005).

The evidence mentioned above supports the possibility of employing plant latex for various treatments. In an attempt to obtain new information on biological properties of jackfruit, a heat stable heteromultimeric glycoprotein (HSGPL1) was purified and characterized from its latex in this work. The effect of HSGPL1 on human blood coagulation time was also investigated.

\section{MATERIALS AND METHODS}

Plant material. The latex used for purification and characterization in this work was obtained from Artocarpus beterophyllus (jackfruit), and was collected from a jackfruit tree in Tambon Pho yai, Warin Chamrap district, Ubon Ratchathani province, Thailand.

Protein extraction and purification. The latex $(25 \mathrm{ml})$ from fruit stem was collected in a clean glass beaker. The whole latex was centrifuged $(13000 \times g$ for $30 \mathrm{~min})$ at room temperature. Then the clear supernatant was transferred to a new tube and heated in a water bath at $90^{\circ} \mathrm{C}$ for $3 \mathrm{~min}$. Aggregated proteins were removed by centrifugation $(13000 \times \mathrm{g}$ for $30 \mathrm{~min})$ and the supernatant was collected for dialysis. The heated supernatant was dialyzed overnight against $50 \mathrm{mM}$ sodium acetate buffer, $\mathrm{pH}$ 4.5. Then the clear supernatant was collected by centrifugation $(13000 \times \mathrm{g}$ for $40 \mathrm{~min})$. The clear supernatant was subjected to purification by $Q$ Sepharose Fast Flow column chromatography $(1.5 \mathrm{~cm} \times 3 \mathrm{~cm})(\mathrm{GE}$ Healthcare, Sweden). The proteins were fractionated with a $0-1 \mathrm{M}$ step gradient of $\mathrm{NaCl}$ in $25 \mathrm{mM}$ Tris/ $\mathrm{HCl}$ buffer, $\mathrm{pH} 8.8$ and flow rate of $1 \mathrm{ml} / \mathrm{min}$. Eluted fractions $(2 \mathrm{ml})$ were collected and the $\mathrm{OD}_{280}$ was meas-

e-mail: jaruwan_siritape@yahoo.com

Abbreviations: OD, optical density; SDS/PAGE, sodium dodecyl sulfate-polyacrylamide gel electrophoresis. 
ured for every fraction. Protein fractions were analyzed further on SDS/12.5\% PAGE.

Determination of protein concentration. Protein concentrations were estimated using the bicinchoninic acid (BCA) assay kit (Pierce, Rockford, USA) according to the manufacturer's instruction. A purified latex protein $(0.1 \mathrm{ml})$ was mixed with $\mathrm{BCA}$ reagent $(2 \mathrm{ml})$. After the reaction mixture was incubated at $37^{\circ} \mathrm{C}$ for $30 \mathrm{~min}$, absorbance at $562 \mathrm{~nm}$ was measured with a spectrophotometer. BSA at various concentrations ranging from $0.025-2.0 \mathrm{mg} / \mathrm{ml}$ was used to construct a standard calibration curve and to determine protein concentrations of unknown samples.

Molecular weight determination of HSGPL1. Gel filtration chromatography on a HiPrep 16/60 Sephacryl S-200 HR column (GE Healthcare, Sweden) was used to determine the molecular weight of HSGPL1 in the heteromultimeric state. The molecular weight markers (Sigma) including hen egg white lysozyme (14.3 kDa), bovine serum albumin (BSA) $(67 \mathrm{kDa})$, sweet potato $\beta$-amylase $(200 \mathrm{kDa})$ were used to estimate the heteromultimeric molecular weights of HSGPL1. A Sephacryl S-200 column $(1.6 \times 60 \mathrm{~cm})$ was pre-equilibrated with $25 \mathrm{mM}$ Tris/ $\mathrm{HCl}, \mathrm{pH}$ 8.8. To determine the void volume $\left(V_{0}\right)$, blue dextran $(1 \mathrm{mg} / \mathrm{ml})(0.5 \mathrm{ml})$ in the equilibration buffer was applied to the column. The column was eluted with the equilibration buffer at a flow rate of $0.5 \mathrm{ml} / \mathrm{min}$. Fractions $(1 \mathrm{ml})$ were collected and their absorbance at $280 \mathrm{~nm}$ was measured. To determine the elution volume $\left(V_{\mathrm{e}}\right)$, each protein was dissolved in elution buffer. Concentration of each standard protein was $4 \mathrm{mg} / \mathrm{ml}$. Each protein sample $(0.5 \mathrm{ml})$ was applied to the column separately and eluted under the same condition as used for blue dextran. To determine the molecular weight of HSGPL1, the ratio of $V_{\mathrm{e}} / V_{0}$ for each standard protein was plotted against its molecular weight on a semi logarithmic scale.

One dimensional SDS/polyacrylamide gel electrophoresis (1D SDS/PAGE). SDS/PAGE was carried out according to the method of Laemmli (1970) on $12.5 \%$ polyacrylamide gel containing $0.1 \%$ SDS using Tris-glycine buffer, $\mathrm{pH}$ 8.8. Bands were visualized by staining with Coomassie brilliant blue R-250.

Two dimensional SDS/polyacrylamide gel electrophoresis (2D SDS/PAGE). Purified latex protein (100 $\mu \mathrm{g})$ was separated in the first dimension on a $7 \mathrm{~cm}$ immobilized $\mathrm{pH}$ gradient strip $\mathrm{pH}$ 3-10 (GE Healthcare, Sweden). The strip was rehydrated for $12 \mathrm{~h}$ and focussed for 9250 Vh using Ettan ${ }^{\mathrm{TM}}$ IPGphor (GE Healthcare, Sweden). Then, it was washed in equilibration buffer containing 5\% iodoacetamide. The second dimension was resolved by $12.5 \%$ Tris-glycine SDS/PAGE. Protein was visualized by staining with colloidal Coomassie brilliant blue G-250. The experimental values of $p I$ and molecular weight for each isoelectric spot were calculated by ImageMasterTM 2D Platinum software (GE Healthcare, Sweden) using reference proteins with known $p I$ and molecular weight.

Effect of SDS and 2-mercaptoethanol on HSGPL1. HSGPL1 was mixed with SDS sample buffer with or without 5\% 2-mercaptoethanol. The sample in each condition was heated $\left(5 \mathrm{~min}, 95^{\circ} \mathrm{C}\right)$ or not prior to separate using 1D SDS/PAGE.

Heat stability determination. HSGPL1 (20 $\mu \mathrm{g})$ was heated at $90^{\circ} \mathrm{C}$ for $5 \mathrm{~min}$. After heating, HSGPL1 was allowed to cool at room temperature for $1 \mathrm{~h}$. Its heat stability was determined by mixing with the SDS sample buffer with or without 2-mercapthoethanol and separa- tion using SDS/12.5\% PAGE. The heated protein bands were compared with the protein bands of unheated HSGPL1 without 2-mercaptoethanol.

Circular dichroism (CD) spectroscopy. CD spectra were determined with a Jasco J-715 spectropolarimeter standardized with CSA (nonhygroscopic ammonium (+)-10-camphorsulfonate). HSGPL1 (1 $\mathrm{mg} / \mathrm{ml}$ in $25 \mathrm{mM}$ Tris/ $\mathrm{HCl}, \mathrm{pH} 8.8$ ) was used and $\mathrm{CD}$ measurements were performed at $25,90^{\circ} \mathrm{C}$ and cooled down to $25^{\circ} \mathrm{C}$, with a scan speed of $20 \mathrm{~nm} / \mathrm{min}, 2 \mathrm{~nm}$ bandwidth, $100 \mathrm{mdeg}$ sensitivity, an average response time of $2 \mathrm{~s}$ and an optical path lenght of $0.2 \mathrm{~mm}$. The baseline buffer was $25 \mathrm{mM}$ Tris/HCl, pH 8.8. The baseline for each temperature was measured and subtracted from the protein spectrum.

Glycosylation. Possible glycosylation of purified proteins was analyzed by the GlycoProfile ${ }^{\mathrm{TM}}$ III fluorescent glycoprotein detection kit (Sigma, USA) after 1D SDSPAGE. After detection, the gel was stained with Colloidal Coomassie brilliant blue G-250.

Deglycosylation. The heteromultimeric form of HSGPL1 was deglycosylated with endoglycosidase $\mathrm{H}$ (Endo $\mathrm{H}$ ) and N-glycosidase F (PNGase F) (New England Biolabs, USA) for $24 \mathrm{~h}$ at $37^{\circ} \mathrm{C}$. Each deglycosylation reaction was composed of HSGPL1 (20 $\mu \mathrm{g}), 10 \mathrm{X}$ glycoprotein reaction buffer $(1 \mu \mathrm{l}), 5000$ units of deglycosylation enzyme and $\mathrm{H}_{2} \mathrm{O}$ to make a $10 \mu \mathrm{l}$ total reaction volume and a separate control reaction contained the same components without enzyme. The deglycosylated protein products were analyzed by non-reducing SDS/PAGE.

Protein identification and peptide mass analysis by MALDI-TOF MS. Protein spots from 2D SDS/ PAGE gels (see above) were excised, destained, reduced, alkylated with iodoacetamide and digested with sequencing-grade trypsin (Promega) following a standard protocol (Shevchenko et al., 1996). After overnight digestion at $37^{\circ} \mathrm{C}$, peptides were extracted and dried in a SpeedVac vacuum centrifuge. A small fraction of these tryptic peptides was used in peptide mass fingerprinting (PMF). PMF was carried out by the BioService Unit (BSU), National Science and Technology Development Agency, Pathumthani, Thailand, using an Autoflex MALDI-TOF mass spectrometer (Bruker Daltonik Bremen, Germany in reflective mode) in an $\alpha$-cyano-4-hydroxycinnamic acid matrix. Databank searching was performed with the MASCOT search engine (http://www.matrixscience. com) based on the Viridiplantae (green plants) of SwissProt 57.7 protein database using the assumption that peptides are monoisotopic. Up to two missed trypsin cleavages was allowed.

Assay for prothrombin time (PT). Plasma was obtained by centrifuging human citrated blood (10 samples) for $15 \mathrm{~min}$ at $1500 \times \mathrm{g}$. Thromboplastin-calcium reagent (HemoStat THROMBOPLASTIN-SI, Human Gesellschaft für Biochemica and Diagnostica mbH, Germany) was reconstituted with distilled $\mathrm{H}_{2} \mathrm{O}$ according to the manufacturer's instructions. Then it was pre-warmed in a water bath at $37^{\circ} \mathrm{C}$ for at least 10 min. Plasma $(100$ $\mu l)$ was placed in a test tube and incubated in water bath for $3-5 \mathrm{~min}$ at $37^{\circ} \mathrm{C}$. For the controls, pre-warmed 25 $\mathrm{mM}$ Tris/HCl, $\mathrm{pH} 8.8(100 \mu \mathrm{l})$, followed by pre-warmed thromboplastin-calcium reagent $(200 \mu \mathrm{l})$ was rapidly pipetted into the plasma while simultaneously starting a timer. The test tube was then gently tilted back and forth until a clot formed, at which time the timer was stopped and the clotting time recorded. For the test samples, each pre-warmed purified latex protein $(100 \mu \mathrm{l})$ in various concentrations $(18.5,37,185,370 \mu \mathrm{g} / \mathrm{ml})$ in 
$25 \mathrm{mM}$ Tris/ $\mathrm{HCl}, \mathrm{pH} 8.8$ was mixed with plasma, just before adding thromboplastin-calcium reagent. All experiments were carried out in duplicate.

Activated partial thromboplastin time (APTT). Ten plasma samples were prepared using the same method as for PT tests. The partial tissue thromboplastin with activator (aPTT-EL reagent) (HemoStat aPT'T-EL, Human Gesellschaft für Biochemica and Diagnostica $\mathrm{mbH}$, Germany) and $0.02 \mathrm{M} \mathrm{CaCl}_{2}$ were pre-warmed to $37^{\circ} \mathrm{C}$ separately in a water bath. One hundred microliters of plasma was placed in a test tube. After incubating for $1-2 \mathrm{~min}$ in a water bath, $100 \mu \mathrm{l}$ of aPT'T-EL reagent was added, and the contents were mixed rapidly. The mixture was then incubated for another 3-5 min, after which $25 \mathrm{mM}$ Tris/ HCl, pH 8.8 (100 $\mu \mathrm{l}$ ) (control), then pre-warmed $20 \mathrm{mM} \mathrm{CaCl}_{2}$ solution $(100 \mu \mathrm{l})$ was added while simultaneously starting a timer. The test tube was then gently tilted back and forth until a clot formed, at which time the timer was stopped and the clotting time recorded. For test samples, pre-warmed purified latex protein $(100 \mu \mathrm{l})$ in various concentrations $(18.5,37,185$, $370 \mu \mathrm{g} / \mathrm{ml}$ ) in $25 \mathrm{mM}$ Tris $/ \mathrm{HCl}, \mathrm{pH} 8.8$ was mixed with the contents of the test tube just prior to addition of $\mathrm{CaCl}_{2}$, with readings taken as before. All experiments were carried out in duplicate.

Serine protease inhibitors. The purified latex protein function as an inhibitor for serine protease of human blood coagulation factors XIa and XIIa (Calbiochem, Germany) was determined using QuantiCleave'TM Protease Assay Kit (Pierce, Rockford, USA). The assay kit uses protease substrate (succinylated casein) and developing color reagent (Trinitrobenzenesulfonic acid; TNBSA) (Hatakeyama et al., 1992; Habeeb, 1966). Proteases, including serine proteases (e.g. some human blood coagulation factors), can cleave peptide bonds of succinylated casein, thereby exposing predominantly $\alpha$-amines (primary amines). The exposed primary amines are reacted with TNBSA to produce an orange-yellow product which can be measured at $450 \mathrm{~nm}$. The increase in color correlates with the protease activity in the sample. The assay method can be modified to determine protease inhibitors (Tian et al., 2004). In this study, the assays were performed in microplates by modifying the manufacturer's instruction. Succinylated casein solution $(100 \mu \mathrm{l})$ was added to microplate wells and assay buffer (50 mM borate, $\mathrm{pH}$ 8.5) $(100 \mu \mathrm{l})$ as substrate blank. Human blood coagulation factors XIa and $\alpha$-XII $(50 \mu \mathrm{l}$ at concentration $16 \mathrm{nM}$ ) were added, followed by purified latex proteins $(50 \mu \mathrm{l}$ with concentrations of $18.5,37,74$, 185 and $370 \mu \mathrm{g} / \mathrm{ml})$ or assay buffer $(50 \mu \mathrm{l})$ for the reaction without the purified latex proteins. The negative control was performed without the protease, by adding purified latex proteins $(50 \mu \mathrm{l}$ with concentrations of 18.5 , $37,74,185$ and $370 \mu \mathrm{g} / \mathrm{ml})$ and assay buffer $(100 \mu \mathrm{l})$. Antithrombin III was used as positive control inhibitor for blood coagulation factors XIa and $\alpha$-XIIa, by adding antithrombin III $(50 \mu \mathrm{l})$ (Calbiochem, Germany) in various concentrations $(0.0625,0.125,0.25,0.5,1,2 \mu \mathrm{M})$. The microplates were incubated for $20 \mathrm{~min}$ at $37^{\circ} \mathrm{C}$. Trinitrobenzenesulfonic acid (TNBSA) $(50 \mu \mathrm{l})$ was added and plates were incubated for $20 \mathrm{~min}$ at room temperature. Microplates were measured for absorbance at 450 $\mathrm{nm}\left(\mathrm{OD}_{450}\right)$ with a microplate reader spectrophotometer. For each well, change in absorbance was calculated by subtracting the $\mathrm{OD}_{450}$ of the blank from that of the corresponding casein well. All tests were done in duplicate.

Detection of proteases. Proteolytic activities of the purified proteins were tested using QuantiCleaveTM
Protease Assay Kit (as described above) and gelatin and casein zymography. Gelatin and casein zymography was used by slightly modifying the method of Shimokawa et al. (2002). Briefly, each purified protein sample was mixed with non-reducing SDS gel sample buffer and applied with or without heating to a $10 \%$ polyacrylamide gel containing $0.1 \%$ SDS and $1 \mathrm{mg} / \mathrm{ml}$ gelatin or casein solution. After electrophoresis, the gel was washed three times in $50 \mathrm{mM}$ Tris/ $\mathrm{HCl}, \mathrm{pH} 7.5$ containing $150 \mathrm{mM}$ $\mathrm{NaCl}, 5 \mathrm{mM} \mathrm{CaCl}_{2}, 5 \mu \mathrm{M} \mathrm{ZnCl}, 0.02 \% \mathrm{NaN}_{3}, 0.025 \%$ Triton X-100 at room temperature, and then incubated in the same buffer without Triton X-100 (two changes) at $37^{\circ} \mathrm{C}$ for $20 \mathrm{~h}$. Proteins were stained with Coomassie brilliant blue R-250. Enzymatic activity was detected as transparent bands.

\section{RESULTS}

\section{Purification and characterization of a heat-stable heteromultimeric glycoprotein from $A$. heterophyllus latex}

Purification and molecular weight determination

A heat stable glycoprotein was extracted and purified from latex of $A$. heterophyllus (jackfruit) using the method described above. Q Sepharose Fast Flow column chromatography revealed a sharp peak of protein, eluted at around $0.4 \mathrm{M} \mathrm{NaCl}$ (Fig. 1). This protein appeared to be heteromultimeric on SDS/PAGE with a molecular mass of more than $97 \mathrm{kDa}$ (Fig. 2) and $150 \mathrm{kDa}$ on size exclusion chromatography (data not shown). The apparent molecular mass of each monomeric protein on SDS/ PAGE was 33 (subunit 1), 31 (subunit 2) and $29 \mathrm{kDa}$ (subuint 3) as shown in Fig. 2a. The isoelectric points $(p I s)$ of the monomers were 6.63 (spot number 1), 6.63 (spot number 2) and 6.93 (spot number 3), respectively (Fig. 2b). The final yield of the protein obtained from latex was approx. $1.12 \%(18.6 \mathrm{mg})$ from $25 \mathrm{ml}$ of latex (Table 1).

\section{Thermostability determination}

CD spectra showed that this protein complex was heat stable (Fig. 3). The protein lost the ordered secondary structure at $90^{\circ} \mathrm{C}$, but, when cooled down to $25^{\circ} \mathrm{C}$, regained its original conformation. The result demonstrated that this protein has an ability to be unfolded and refolded to the conformation with the lowest free

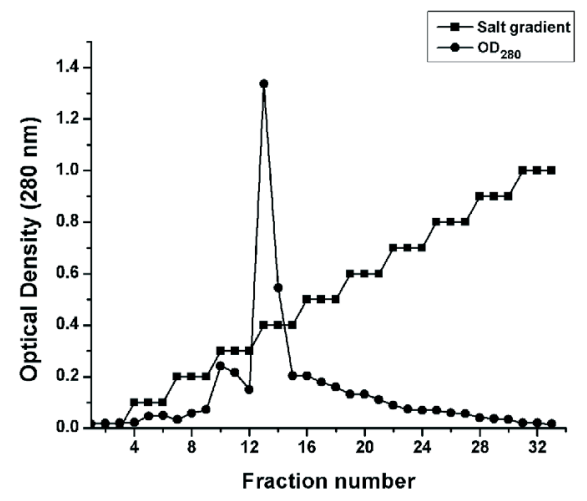

Figure 1. Purification of HSGPL1 from jackfruit latex using $Q$ Sepharose Fast Flow column chromatography. HSGPL1 was eluted by $0.4 \mathrm{M} \mathrm{NaCl}$ (Fraction number 12-16). 
A)

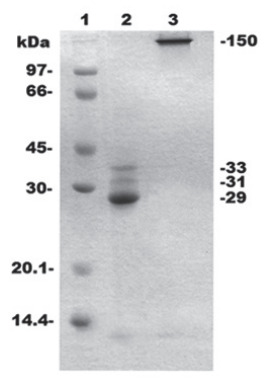

B)

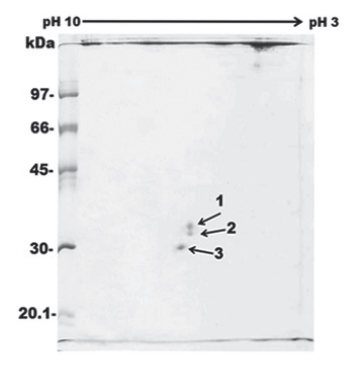

Figure 2. 1D and 2D SDS/PAGE of HSGPL1 and its monomers purified from jackfruit latex.

(A) Samples $(5 \mu \mathrm{g})$ were solubilized in $5 \mathrm{X}$ SDS sample buffer containing 2-mercaptoethanol and were unheated (lane 3) or heated (lane 2). Lane 1 contains molecular weight markers. pls of proteins were established by 2D-PAGE (B).

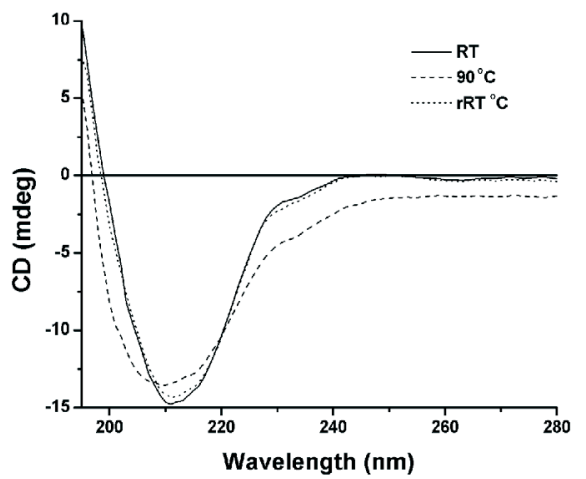

Figure 3. Far-UV CD spectra of HSGPL1.

The spectra were recorded at $25^{\circ} \mathrm{C}(\mathrm{RT}), 90^{\circ} \mathrm{C}$ and after returning the temperature to $25^{\circ} \mathrm{C}$ (rRT).
A)

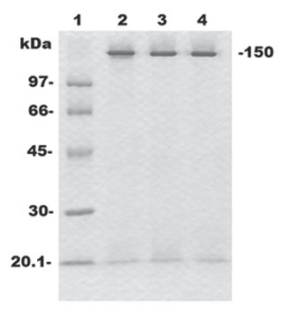

B)

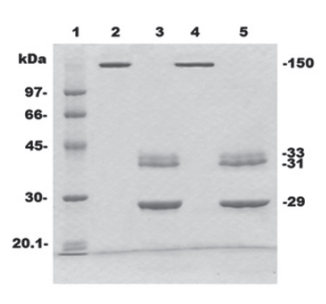

Figure 4. Heat stability and 2-mercaptoethanol resistance of HSGPL1.

(A) Heat stability of HSGPL1 was evaluated by comparison between unheated native HSGPL1 (lane 2) and heated HSGPL1 with or without 2-mercaptoethanol (lanes 3 and 4, respectively). (B) HSGPL1 was tested for resistance to reduction with 2-mercaptoethanol. Lane 2 contains sample mixed with 2-mercaptoethanol, but not heated; lane 3, sample with 2-mercaptoethanol and heated. Lane 4 contains unheated sample without 2-mercaptoethanol; lane 5, heated without 2-mercaptoethanol. Both A and B show SDS $/ 12.5 \%$ PAGE and lane 1 contains protein molecular weight markers.

Table 1. Purification of HSGPL1 from jackfruit latex. Results are average values of two separate experime

\begin{tabular}{lll}
\hline Purification step & $\begin{array}{l}\text { Total prote- } \\
\text { in }(\mathrm{mg})\end{array}$ & $\begin{array}{l}\text { Yield } \\
(\%)\end{array}$ \\
\hline $\begin{array}{l}\text { 1. Crude latex protein } \\
\text { 2. Supernatant after heating }\end{array}$ & 1662.2 & 100 \\
$\begin{array}{l}\text { 3. Dialysis against 50 mM sodium } \\
\text { acetate, pH 4.5 }\end{array}$ & 807.8 & 48.6 \\
$\begin{array}{l}\text { 4. Q sepharose anion exchange } \\
\text { chromatography (HSGPL1 fraction) }\end{array}$ & 18.6 & 5.2 \\
\hline
\end{tabular}

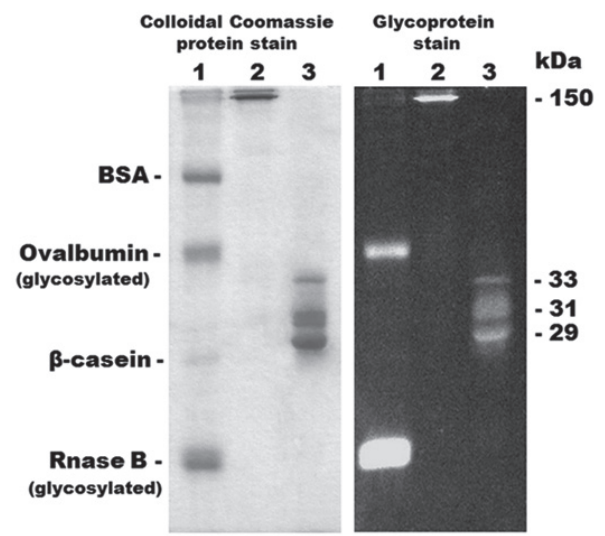

Figure 5. Glycoprotein staining of HSGPL1 proteins.

In the glycoprotein stain (right), Lane 1 contains marker proteins. Glycosylated markers are ovalbumin and Rnase B, and non-glycosylated markers are bovine serum albumin (BSA) and $\beta$-casein. Lanes 2 and 3 are HSGPL1 and its monomers, respectively. After the glycoprotein stain, the gel was stained with colloidal Coomassie briliant blue G-250 (left).

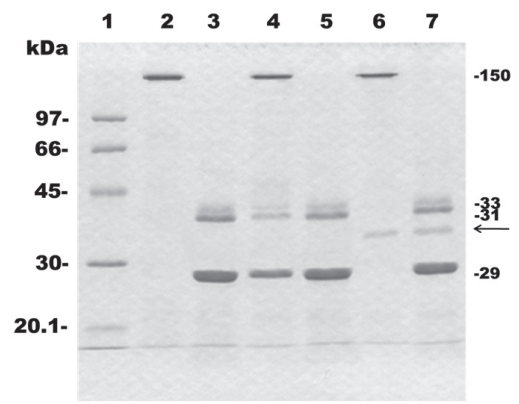

Figure 6. Deglycosylation of HSGPL1.

HSGPL1 was deglycosylated by Endo $H$ (lanes 4 and 5) and PNGase $F$ (lanes 6 and 7) and compared to protein incubated without enzyme under the same conditions (lanes 2 and 3). After deglycosylation each sample was mixed with SDS-sample buffer without 2-mercaptoethanol and the proteins were separated by non-reducing SDS/PAGE. Each unheated sample (lanes 2, 4 and 6) was compared with samples heated for $5 \mathrm{~min}$ in a boiling water bath (lanes 3, 5 and 7). Lane 1 contains protein molecular weight markers. Arrow indicates PNGase F.

energy. The heat stability of this heteromultimeric protein was shown more directly by heat stability determination experiment. The protein complex was not destroyed by heating (Fig. 4a).

SDS and reducing agent resistance determinations

The protein complex was not destroyed by reducing agent (2-mercaptoethanol) and SDS (lanes 2 and 4 of Fig. $4 \mathrm{~b}$, respectively). In contrast, if the multimeric protein was mixed with SDS sample buffer with and without 2-mercaptoethanol and heated at $90^{\circ} \mathrm{C}$ for $5 \mathrm{~min}$, it was completely dissociated to three monomeric forms (lanes 3 and 5 of Fig. 4b, respectively).

Glycosylation and deglycosylation

A glycosylation test confirmed that this heat-stable multimeric protein and all of its monomers were glycoproteins (Fig. 5). Deglycosylation of the native multimeric protein was attempted with Endo $\mathrm{H}$ and PNGase F. The native multimeric form was sensitive to deglycosylation with Endo H, but not with PNGase F (Fig. 6). Since this heteromultimeric protein purified from jack- 


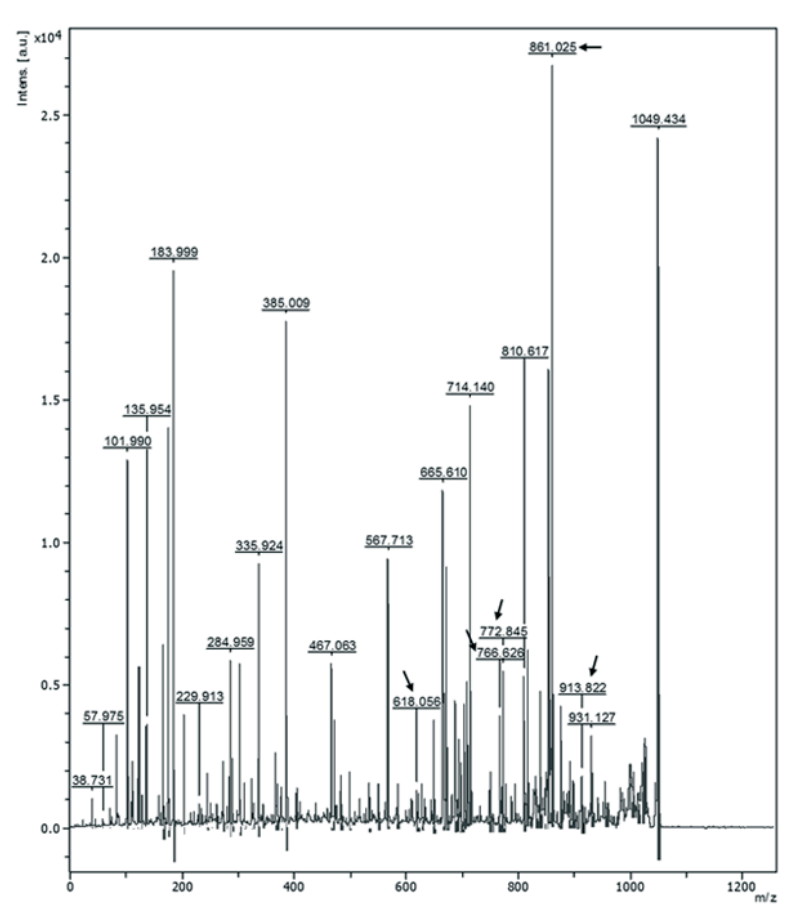

Figure 7. MALDI-TOF mass spectrometry analysis of spot number 1.

Example of a peptide mass fingerprint of a monomer of HSGPL1 (33 kDa). Peptide mass fingerprint of the observed mass was performed using the MASCOT search engine. Observed masses (10 of 67 masses) were matched to $26.779 \mathrm{kDa}$ of a small heat-shock protein of Petunia hybrida. Then matched masses were converted to amino acid sequences along variable residue sites and covered $24 \%$ of the protein sequence.

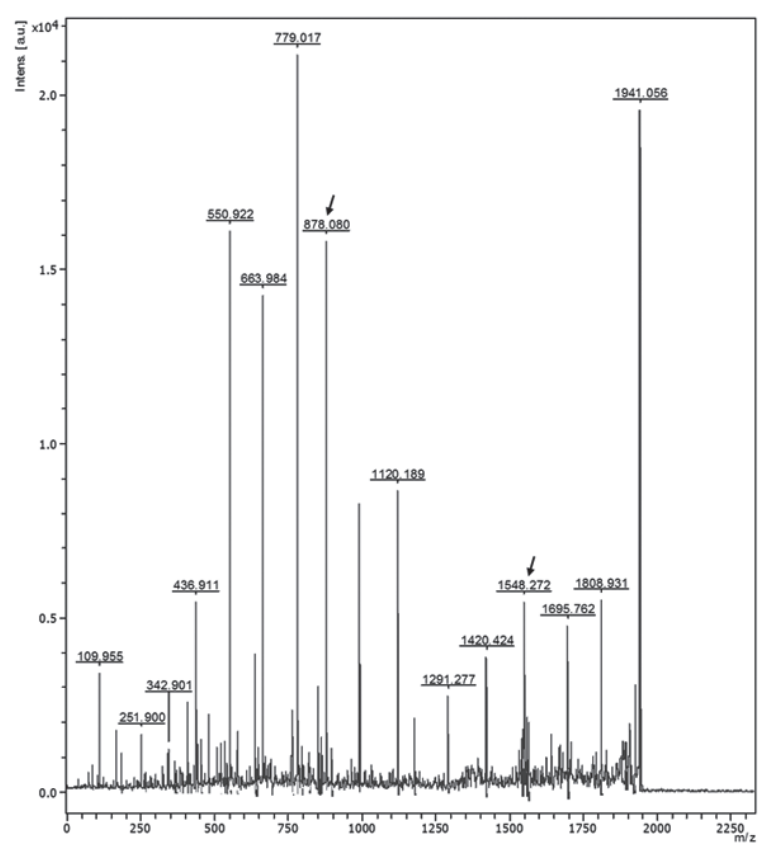

Figure 8. MALDI-TOF mass spectrometry analysis of spot number 2.

Example peptide mass fingerprint of a monomer of HSGPL1 (31 $\mathrm{kDa}$ ). Peptide mass fingerprint of the observed mass was performed using the MASCOT search engine. Observed masses (11 of 77 masses) were matched to $60.429 \mathrm{kDa}$ of the chaperonin CPN60-like 2 of Arabidopsis thaliana. Then matched masses were converted to amino acid sequences along variable residue sites and covered $14 \%$ of the protein sequence.

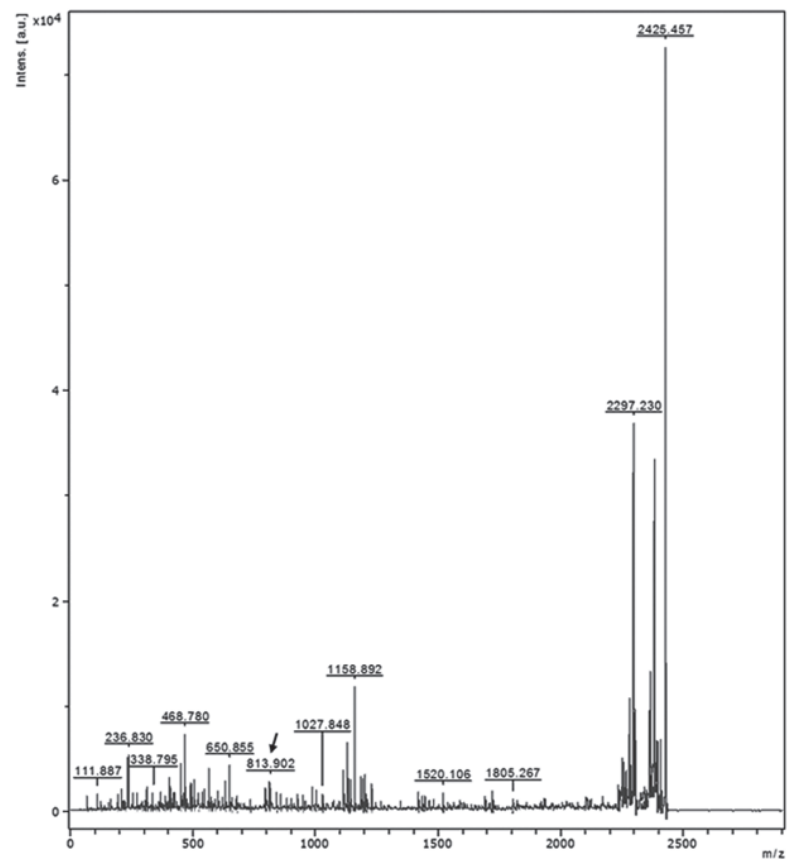

Figure 9. MALDI-TOF mass spectrometry analysis of spot number 3.

Example of a peptide mass fingerprint of a monomer of HSGPL1 $(29 \mathrm{kDa})$. Peptide mass fingerprint of the observed mass was performed using the MASCOT search engine. Observed masses (13 of 129 masses) were matched to $25.328 \mathrm{kDa}$ of a small heat-shock protein of Arabidopsis thaliana. Then matched masses were converted to amino acid sequences along variable residue sites and covered $46 \%$ of the protein sequence.

fruit latex was a glycoprotein and was heat stable, it was designated heat-stable glycoprotein from latex 1 (HSGPL1).

Protein identification

Three spots of different isoelectric points and molecular weights of HSGPL1 were identified by MALDI-TOF MS. Peptide mass fingerprints were obtained from MALDI-TOF mass spectrometry using the MASCOT search engine to query the SwissProt 57.7 protein database allowing up to two missed cleavages. The result for spot number 1 in the peptide mass fingerprinting is shown in Fig. 7. The peptide mass fingerprint was identified as similar to a small heat-shock protein of Petunia bybrida. Spot number 2 in the peptide mass fingerprinting is shown in Fig. 8. The peptide mass fingerprint was identified as chaperonin CPN60-like 2 of Arabidopsis thaliana. The spot number 3 in the peptide mass fingerprinting is shown in Fig. 9. The peptide mass fingerprint of spot number 3 was identified as a small heat-shock like protein of Arabidopsis thaliana.

\section{Functional assays of HSGPL1}

\section{The Effect of HSGPL1 on human blood coagulation time}

The effect of HSGPL1 on human blood coagulation was examined by mixing various concentrations of HSGPL1 $(18.5,37,185,370 \mu \mathrm{g} / \mathrm{ml})$ in $25 \mathrm{mM}$ Tris/ $\mathrm{HCl}$, $\mathrm{pH} 8.8$, with $100 \mu \mathrm{l}$ of 10 samples of human plasma individually to coagulate in the PT test and APTT tests. The results of the tests are shown in Table 2. HSGPL1 had no significant effect on the PT at any concentration, 


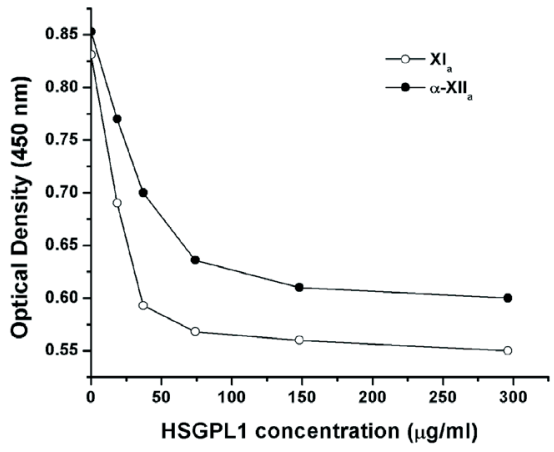

Figure 10. Functional activity assay of HSGPL1 as serine protease inhibitor.

HSGPL1 was tested with human blood coagulation factors $\mathrm{XI}_{\mathrm{a}}$ and a-XII. Enzyme and HSGPL1 were mixed and allowed to interact for $20 \mathrm{~min}$ at $37^{\circ} \mathrm{C}$. Protease activity against succinylated casein as substrate was assayed as specified in the Materials and Methods.

Table 2. Effect of HSGPL1 on prothrombin time (PT) and activated partial thromboplastin time (APTT).

\begin{tabular}{lll}
\hline HSGPL1 $(\mu \mathrm{g} / \mathrm{ml})$ & PT $(\mathrm{s})$ & APTT $(\mathrm{s})$ \\
\hline Control (Tris/HCl, pH 8.8) & $15.7 \pm 2.8 \mathrm{a}$ & $44.6 \pm 4.8 \mathrm{a}$ \\
18.5 & $15.5 \pm 2.5 \mathrm{~b}$ & $43.8 \pm 4.3 \mathrm{~b}$ \\
37 & $15.8 \pm 2.3 \mathrm{~b}$ & $44.9 \pm 5.2 \mathrm{~b}$ \\
185 & $16.1 \pm 2.5 \mathrm{~b}$ & $61.5 \pm 7.8 \mathrm{c}$ \\
370 & $16.3 \pm 2.5 \mathrm{~b}$ & $79.0 \pm 10.1 \mathrm{c}$ \\
\hline
\end{tabular}

Values are mean \pm S.D. $(n=10)$. Evaluation of the effect of HSGPL1 on blood coagulation was performed using Student's $t$-test for independent samples. For PT, letter (b) is not significantly different from letter (a) at $P>0.05$. For APTT, letter (b) is not significantly different from letter (a) at $P>0.05$. Letter (c) is significantly different from letter (a) at $P<0.05$.

whereas it had a significant effect on APT'T by prolonging clotting time proportionally to the increasing concentration.

Proteolytic and serine protease inhibitor activities

Both gelatin and casein zymography were employed to confirm that HSGPL1 and its monomers had no protease activity (not shown). HSGPL1 also had no protease activity in soluble form analyzed by QuantiCleave'TM Protease Assay Kit (not shown). Since some of the intrinsic factors are serine proteases (Hayashi et al., 1994), the inhibitory effect of HSGPL1 on serine protease was determined. The activity of serine protease inhibitor was determined in terms of inhibition of proteolytic activity of human blood coagulation factors $\mathrm{XI}_{\mathrm{a}}$ and $\alpha-\mathrm{XII}_{\mathrm{a}}$, The results shown in Fig. 10 indicate that HSGPL1 indeed shows an antiproteolytic activity.

\section{DISCUSSION}

In this study a $150-\mathrm{kDa}$ heat stable heteromultimeric glycoprotein (HSGPL1) from milky latex of jackfruit tree was isolated and purified using heat precipitation and anion exchange chromatography. CD spectra and heat stability determination revealed that this protein complex was not denatured irreversible by thermal treatment. Its structure is flexible as it is disordered at high temperature $\left(90^{\circ} \mathrm{C}\right)$ and regains its native form when cooled down to room temperature at $25^{\circ} \mathrm{C}$. The characteristics of this protein upon heat treatment are similar to those of other heat stable proteins, for instance, heat-stable microtubule-associated protein MAP2 (Hernández et al., 1986), a heat-stable phytase from the fungus Aspergillus fumigatus (Pasamontes et al., 1997) and late embryogenesis-abundant (LEA) soy bean proteins (Shih et al., 2010). The heat stability of HSGPL1 was also confirmed by the result that its native multimer was not dissociated after heating at $90^{\circ} \mathrm{C}$. Moreover, the multimer also resisted SDS and reducing agent (2-mercatoethanol) treatment at room temperature. The multimer dissociated into subunits upon heating with SDS even in the absence of 2-mercaptoethanol, which indicates that the subunits were not linked by disulphide bridges.

Glycosylation test confirmed that the multimer of HSGPL1 and all of its monomers were glycoproteins. $N$-glycans of HSGPL1 were removed using Endo $\mathrm{H}$ and it emphasized that each subunit of this protein formed complex through the sugar-based interactions (Chen et al., 1991).

The results of peptide mass fingerprint searches showed that all three spots of HSGPL1 were related to plant heat-shock proteins (Hsps) and a related chaperonin. Hsps/chaperones are functionally related proteins whose expression is increased when cells are exposed to elevated temperature or other stress (Wang et al., 2004). In the present study, HSGPL1 was identified as a multimeric glycoprotein. These properties of HSGPL1 were related with heat-stable the group of plant stress glycoprotein including Hsps/chaperone (Jethmalani \& Henle, 1998; Sreedhar et al., 2010). Plant stress glycoproteins can form complexes by various specific types of interactions with both glycosylated and unglycosylated proteins (Jethmalani \& Henle, 1998). In this study, each monomer of HSGPL1 was form complex by carbohydrate interaction. In addition, they are key components contributing to cellular homeostasis in cells under optimal and adverse growth conditions. They also function in the stabilization of proteins and membranes, and can assist in protein refolding under stress conditions (Carranco et al., 1997; Wang et al., 2004). Another property of Hsps is that they act as protease inhibitors, for instance, heat shock protein 47 (Hsp 47) which is known as SERPINH 1 (Dafforn et al., 2001). This protein is a member of the serpin superfamily of serine protease inhibitors (Dafforn et al., 2001). Its expression is induced by heat-shock.

The results of peptide mass fingerprinting suggested that HSGPL1 is a complex protein which may contribute to cellular homeostasis in normal and stress conditions of jackfruit, or have a role as a Hsps/chaperone. New biological properties of HSGPL1 from jackfruit latex were investigated in this study. These investigations focused on the protease and protease inhibitor properties which acted on the human blood coagulation system. The effects of this protein on human blood coagulation factors were determined using the prothrombin time (PT) and the activated partial thromboplastin time (APT'T) tests. The human blood clotting process is very complex and involves intrinsic, extrinsic and common pathways (Brown, 1988). The prothrombin time test is an in-vitro test to assess human blood coagulation factors in the extrinsic and common pathways. Prothrombin time is performed by adding a mixture of calcium and thromboplastin to the test plasma. The length of time, in seconds, for the sample to clot is the prothrombin time (PT) (Brown, 1988). The activated partial thromboplastin time (APT'T) is a measure of the functions of the intrinsic and common pathways of the coagulation cascade. The APT'T is the time, in seconds, for human plasma to clot after the addition of an intrinsic pathway activator, phospholipid and calcium (Shih et al., 2010). HSGPL1 had an effect on the intrinsic pathway of plasma clot- 
ting factors (VIII, IX, XI, XII and prekallikrein (Fletcher factor) since it prolonged the APTT time. The plasma clotting factors (V, VII, X, prothrombin and fibrinogen) of the extrinsic and common pathways were not affected by HSGPL1.

The human blood coagulation factors XIa and $\alpha$-XIIa were selected to test for specific serine protease inhibitor property of HSGPL1, since both factors are important in the initiation of the intrinsic system. HSGPL1 reduced the activity of blood coagulation factors XIa and $\alpha$-XIIa. The results of PMF showed that HSGPL1 was Hsps/chaperone which could inhibit some human blood coagulation factors by specific binding. Specific binding of HSGPL1 to intrinsic blood coagulation factors can alter their folding or conformation which may affect their functional cascades (Jethmalani \& Henle, 1998). Moreover, the family of protease inhibitors also includes the plasma proteins $\alpha 1$-antitrypsin, $\alpha 1$-antichymotrypsin, antithrombin, plasminogen activator inhibitor 1 (PAI-1) and C1q-inhibitor (Maier \& Meier, 2002). These proteins have regulatory functions in the inflammatory, complement, blood coagulation and fibrinolytic cascades (Maier \& Meier, 2002). Consequently, more biological properties of HSGPL1 will be investigated in further study.

The protease inhibitor property of HSGPL1 is very useful in modern and traditional medicine, because protease inhibitors are involved in blood coagulation, fibrinolysis, angiogenesis, wound healing, and tumor invasion (Bode \& Huber, 2000; Ivanciu et al., 2007).

In conclusion, this work demonstrates the serine protease inhibitory property of a heteromultimeric glycoprotein purified from jackfruit latex. This protein affects the intrinsic factors of human blood coagulation by prolonging the APT'T and inhibiting blood coagulation factors $\mathrm{XIa}$ and $\alpha$-XIIa. In addition, this protein was provisionally identified as a heat-shock/chaperone protein. These properties may be a medicinal benefit, e.g., in wound healing, blood coagulation and fibrinolysis. Since a large number of human disorders results from an imbalance in proteolytic activity, this inhibitor may help regulate and balance protease activities in endogenous defense system. HSGPL1 may be a natural protease inhibitor useful for thrombosis treatment.

\section{Acknowledgements}

We gratefully thank the Thailand Research Fund (TRF) and the Commission on Higher Education (CHE), Ministry of Education (GRANT MRG5180004), Protein and Proteomic Research Group, Department of Biochemistry, Faculty of Science, Khon Kaen University for supporting this research.

We would like to thank Dr. Chartchai Kritanai of the Institute of Molecular Biology and Genetics, Mahidol University, Salaya, Thailand for providing facilities for circular dichroism measurements and analyses. We are grateful to Mr. Ian Thomas (Department of Physics, Faculty of Science, Khon Kaen University, Thailand) for critical review of the manuscript.

\section{REFERENCES}

Ajayi IA (2008) Comparative study of the chemical composition and mineral element content of Artocarpus beterophyllus and Treculia africana seeds and seed oils. Bioresour Technol 99: 5125-5129.

Bode W, Huber R (2000) Structural basis of the endoproteinase-protein inhibitor interaction. Biochim Biophys Acta 1477: 241-252.

Bohlooli S, Mohebipoor A, Mohammadi S, Kouhnavard M, Pashapoor S (2007) Comparative study of fig tree efficacy in the treatment of common warts (Verruca vulgaris) vs. cryotherapy. Int J Dermatol 46: 524-526.

Brown BA (1988) Haematology: Principles and Procedures. pp 195-215. Lea and Febiger, Philadelphia.

Carranco R, Almoguera C, Jordano J (1997) A plant small heat shock protein gene expressed during zygotic embryogenesis but noninducible by heat stress. J Biol Chem 272: 27470-27475.

Chen LL, Rosa JJ, Turner S, Pepinsky RB. (1991) Production of multimeric forms of CD4 through a sugar-based cross-linking strategy. $J$ Biol Chem 266: 18237-18243.

Dafforn TR, Della M, Miller AD (2001) The molecular interactions of heat shock protein 47 (Hsp47) and their implications for collagen biosynthesis. J Biol Chem 276: 49310-49319.

Fernando MR, Wickramasinghe N, Thabrew MI, Ariyananda PL, Karunanayake EH (1991) Effect of Artocarpus heterophyllus and Asteracanthus longifolia on glucose tolerance in normal human subjects and in maturity-onset diabetic patients. J Ethnopharmacol 31: 277-282.

Fonseca KC, Morais NC, Queiroz MR, Silva MC, Gomes MS, Costa JO, Mamede CC, Torres FS, Penha-Silva N, Beletti ME, Canabrava HA, Oliveira F (2010) Purification and biochemical characterization of Eumiliin from Euphorbia milii var. hislopii latex. Phytochemistry 71: $708-715$.

Gurung S, Skalko-Basnet N (2009) Wound healing properties of Carica papaya latex: in vivo evaluation in mice burn model. $J$ Ethnopharmacol 121: 338-341.

Habeeb AF (1996) Determination of free amino groups in proteins by trinitrobenzenesulfonic acid. Anal Biochem 14:328-336.

Hatakeyama T, Kohzaki H, Yamasaki N (1992) A microassay for proteases using succinylcasein as a substrate. Anal Biochem 204: 181184.

Hayashi K, Takehisa T, Hamato N, Takano R, Hara S, Miyata T, Kato $H$ (1994) Inhibition of serine proteases of the blood coagulation system by squash family protease inhibitors. J Biochem 116: 1013 1018 .

Hernández MA, Avila J, Andreu JM (1986) Physicochemical characterization of the heat-stable microtubule-associated protein MAP2. Eur J Biochem 154: 41-48.

Ivanciu L, Gerard RD, Tang H, Lupu F, Lupu C (2007) Adenovirusmediated expression of tissue factor pathway inhibitor- 2 inhibits endothelial cell migration and angiogenesis. Arterioscler Thromb Vasc Biol 27: 310-316.

Jethmalani SM, Henle KJ (1998) Interaction of heat stress glycoprotein GP50 with classical heat-shock proteins. Exp Cell Res 239: 23-30.

Kabir S (1995) The isolation and characterisation of jacalin [Artocarpus heterophyllus (jackfruit) lectin] based on its charge properties. Int J Biochem Cell Biol 27: 147-156.

Laemmli UK (1970) Cleavage of structural proteins during the assembly of the head of bacteriophage T4. Nature 227: 680-685.

Maier W, Meier B (2002) Mechanical Treatment to Stabilize Plaque. In Mechanical Treatment to Stabilize Plaque. Brown DL, pp 401-426. Marcel Dekker, New York, London.

Mekkriengkrai D, Ute K, Swiezewska E, Chojnacki T, Tanaka Y, Sakdapipanich JT (2004) Structural characterization of rubber from jackfruit and euphorbia as a model of natural rubber. Biomacromolecules 5: 2013-1019.

Osoniyi O, Onajobi F (2003) Coagulant and anticoagulant activities in Jatropha curcas latex. J Ethnopharmacol. 89: 101-105.

Pasamontes L, Haiker M, Wyss M, Tessier M, van Loon AP (1997) Gene cloning, purification, and characterization of a heat-stable phytase from the fungus Aspergillus fumigatus. Appl Environ Microbiol 63: 1696-1700.

Prasad KMR, Virupaksha TK (1990) Purification and characterization of a protease from jackfruit latex. Phytochemistry 29: 1763-1766.

Shevchenko A, Wilm M, Vorm O, Mann M (1996) Mass spectrometric sequencing of proteins from silver-stained polyacrylamide gels. Anal Chem 68: 850-858.

Shih MD, Hsieh TY, Lin TP, Hsing YI, Hoekstra FA (2010) Characterization of two soy bean (Glycine max L.) LEA IV proteins by circular dichroism and Fourier transform infrared spectrometry. Plant Cell Physiol 51: 395-407.

Shimokawa K, Katayama M, Matsuda Y, Takahashi H, Hara I, Sato H, Kaneko S (2002) Matrix metalloproteinase (MMP)-2 and MMP-9 activities in human seminal plasma. Mol Hum Reprod 8: 32-36.

Shivaprasad HV, Rajesh R, Nanda BL, Dharmappa KK, Vishwanath BS (2009) Thrombin like activity of Asclepias curassavica L. latex: action of cysteine proteases. J Ethnopharmacol 123: 106-109.

Shyamalamma S, Chandra SB, Hegde M, Naryanswamy P (2008) Evaluation of genetic diversity in jackfruit (Artocarpus beterophyllus Lam.) based on amplified fragment length polymorphism markers. Genet Mol Res 7: 645-656.

Sreedha AS, Vanathi P, Rao K (2010) Stress proteins in biology and medicine: evolution, adaptation and clinical evaluation. Int J Pharma Bio Scis 1: 1-36.

Tian M, Huitema E, Da Cunha L, Torto-Alalibo T, Kamoun S (2004) A Kazal-like extracellular serine protease inhibitor from Phytophthora 
infestans targets the tomato pathogenesis-related protease P69B. I Biol Chem 279: 26370-26377.

Toma W, Hiruma-Lima CA, Guerrero RO, Brito AR (2005) Preliminary studies of Mammea americana L. (Guttiferae) bark/latex extract point to an effective antiulcer effect on gastric ulcer models in mice. Phytomedicine 12: 345-350.
Wang W, Vinocur B, Shoseyov O, Altman A (2004) Role of plant heat-shock proteins and molecular chaperones in the abiotic stress response. Trends Plant Sci 9: 244-252. 